\title{
Epidemics in Modern and Contemporary Age in a Backward Area of Europe: The Role of Institutions and Socio-Economic Effects in Southern Italy
}

\author{
Vittoria Ferrandino \\ Marilena Iacobaccio \\ Valentina Sgro \\ University of Sannio, Benevento (Italy)
}

\section{Abstract}

Ethics as a cure for anxiety, or rather for anxieties, a distinctive feature of contemporary western man, neurotic and afraid. Man cannot be only that aggregate of primitive instincts driven by selfishness and individual interest that utilitarianism has credited and neoliberalism has emphasized. It seems obvious that the Covid-19 effect amplifies these paradoxes and anxieties. Epidemics are certainly not new in the historical-social context. The purpose of this study will be to analyze some of the numerous epidemics that have occurred in history and their impact on the economy. The corrections can only come from a re-evaluation of the ethical state, the ethical family and a new ethical world: attention to migratory phenomena through the principle of the obligation to rescue the least of the earth; relaunch of the international organizations with which the world, in the happy post-war season, had intended to give an order that guaranteed peace and balance, but which has gradually been forgotten; reduction of wage differences; taxation of capital and presence of the public interest in the company's governing bodies. Through the analysis of original sources, such as the historical archive of Pio Monte della Misericordia and Banco di Napoli, the study will compare the plague of 1656, and the effects of the intervention of charities in support of the population with the socio-economic impact of the Spanish influence in the first decades of the twentieth century, up to the current pandemic, with particular attention to the consequences on the production capacity of goods and services in a backward area of Europe, such as Southern Italy. *

Keywords: economic history; social sciences; economic impact; epidemics 


\section{Introduction}

\section{The 1656 Plague Epidemic in the Kingdom of Naples: spread and socio- economic effects}

Throughout history, there have been numerous epidemics that have affected the population. There are several figures of scholars who have written about it, passing on scientific, social and economic data. The plague is certainly one of the largest epidemics, which has occurred periodically over the years, starting with "The black plague of 1347", up to the last and serious episodes of pestilence that characterized the seventeenth century.

Plague (bubonic, septicemic, pulmonary) was a widespread disease in the ancient regime, which was often confused with other diseases. The doctors of the time could hardly identify and contrast it, so every time it reappeared it involved changes in the demographic, social and economic levels.

«A vessel loaded with leather and other hides, coming from Algieri brought the plague to Valenza», as Bindio writes and who, just like other scholars claims that in 1647 the disease spread to Spain starting from the shoemakers of Valencia. The plague advanced rapidly and after a few months from Valencia it had passed to the neighboring cities, causing thousands of victims in Ciche, Alicante, Cartaghena, Striglia and Cadiz. Not even Barcelona and its entire region was spared.

From 1652, the disease spread to Sardinia (already recovering from a plague that struck Alghero in 1582, causing over 6000 deaths in a few months, with only 150 survivors 12345 However, in this case, «thanks to the doctor 6 the plague did not leave the borders of Alghero and the island was spared»), first in Sassari, then moving to the Sardinian capital in 1655 and then to the cities and territories of Naples, Rome

\footnotetext{
*Authors agree on the entire paper, however paragraphs 1 and 2 are due to Marilena Iacobaccio, paragraphs 3 and 4 to Valentina Sgro, and paragraphs 5 and 6 to Vittoria Ferrandino.
}

2 Pascale Bindio, Napoli nell'anno 1656: ovvero, Documen dellapeslenza che desold Napoli nell'anno 1656, 1867

3 See Maiso Gonzalez, La peste aragonesa de 1649 a 1652, Departamento de Historia Moderna, Universidad de Zaragoza, Zaragoza, 1982; V. Perez Moreda, Las crisis de mortalidad en la Espana interior (siglos XVI-XIX), Siglo veintiuno de Espana editores s.a., Madrid, 1980

4 F. Manconi, Castigo de Dios. La grande peste barocca nella Sardegna di Filippo IV, Donzelli, Rome, 1994

${ }^{5}$ F. Montanaro, La peste del 1656 nel casale di Frattamaggiore: i fatti nei documenti originali dell'epoca, in coll. Novissimae Editiones, series 17, Raccolta Rassegna Storica dei Comuni - Vol. 16 Year 2002, edited by Giacinto Libertini, Istituto Di Studi Atellani, year XXVIII (n. s.), n. 112-113 mayaugust 2002, december 2010, p. 155

6 The doctor referred to is Q. T. Angelerio who described the symptoms of the disease and the best precautions to combat it in the volume Epidemiologia, sive, tractatus de peste, ad regni Sardiniae progeren, Madrid, Ex Typographia Regia, 1598. 


\section{and Genoa.}

In the Kingdom of Naples the plague broke out in 1656 causing considerable damage not only to the population, but also to the southern economic and social system 1 .

Naples was the first city to be hit within the Kingdom, there are several theses supported on how it got there. For some it was carried by passengers on a ship from Sardinia, for others by some boats loaded with hides and other merchandise or for others still from a ship carrying Spanish soldiers ${ }^{2} 34$. The doctor Giuseppe Bozzuto was among the first to diagnose the plague in February, as shown by the payment coupons in his name kept in the Banco di Napoli Historical Archive. The doctor Geronimo Gatta, on the other hand, would trace the first cases of plague, even to the middle of January 5 as claimed by Rubino ${ }^{6}$. However among the archive sources 78 the predominant thought is that the infection spread in March, making the maximum expansion of the infection from that month until May of the same year. Propagation was favored by the delay with which the disease was recognized and the late contrast measures adopted. The epidemic affected Naples until the following August ${ }^{9}$, but only from December 1656 Naples could declare itself plague free ${ }^{10}$.

The closure of the city is one of the first law enforcement actions, with limitations on movement and a ban on trade. Infact it needed a health report, certifying the state of

\footnotetext{
1 I. Fusco, Il ruolo dei fattori antropici e fisici nella diffusione dell'epidemia di peste del 1656-58 nel Regno di Napoli, Istituto di Studi sulle Societa del Mediterraneo, «Popolazione e Storia», 2/2015, Naples, pp. 95-113

2 For further information, I. Fusco, La peste del 1656-58 nel Regno di Napoli: diffusione e mortalita, Istituto di studi sulle societa del Mediterraneo, «Popolazione e Storia», 1/2009, Naples, p. 116

${ }^{8}$ Archivio di Stato di Napoli (from now on ASN), Segreterie dei Vicere, Scritture diverse, fascio 206, fasc. 152; agosto 1656, this thesis was also supported by S. De Renzi, Napoli nell'anno 1656, Celi, Naples, 1968 [1867].

9Societa Napoletana di Storia Patria (from now on SNSP), ms. XXI.C.23, f. 456; D.A. Parrino, Teatro eroico e politico de' governi de' Vicere del Regno di Napoli, 3, in the new Stampa del Parrino e del Mutii, Naples, 1694, p. 33

${ }^{10}$ S. De Renzi, Napoli nell'anno 1656, cit., pp. 35-36
}

6 SNSP, ms. XXIII.D.14, A. Rubino, Notitia di quanto e occorso in Napoli dall'anno 1648 per tutto l'anno 1657, tomo I, ff. 218-219

7 Cf. S. De Renzi, Napoli nell'anno 1656, cit. p. 37 note 1; SNSP, ms. XXVI.D.5, G. Campanile, Cose degne di memoria della citta di Napoli, f. 681; Furthermore, ASN, Segreterie dei Vicere, Scritture diverse, cit., fascio 217, fasc. 126 (17 november1657)

8 ASN, Segreterie dei Vicere, Scritture diverse, fascio 208, fasc. 136 e fascio 205, fasc. not numberd; 17 may 1656

9 Ibidem

10Ibidem, fasc. 158 
health, to enter or leave the city ${ }^{123}$. Despite the prohibitions imposed, the population tried to escape from the city of Naples, where the plague advanced rapidly. It is therefore no coincidence that the first infected territories were the closest to the capital: primarily the Terra di Lavoro and subsequently the Contado di Molise and the two Abbruzzi . The escape that involved as many nobles and religious as the common people, later touched also the southern areas of the Kingdom, arriving in areas increasingly distant from the capital ${ }^{4}$.

Numerous remedies were adopted, researched and applied in the field, both as a preventive and at a curative level. They range from health to religious and mystical ones, sometimes even very imaginative. In the first place, attempts were made to avoid contact between healthy individuals and assaults. Once the plague victims were identified, they were isolated in special lazarets, the corpses were transported away from the inhabited center and the infected objects were burned 56 . Only later did the «purge» proceed, that is, the destruction or disinfection of all that had come into contact with the pandemic . Once this procedure was also completed, a quarantine period was carried outto prevent new outbreaks . Obviously the most relevant remedy was the one adopted a priori, which today we will call social distancing .

The results were rather disappointing, in fact there were huge numbers of deaths. Despite the difficulty of defining demographic data precisely, it can be said that the number of victims of the infection was between a minimum of 400,000 and a maximum of 900,000 throughout the Kingdom, excluding the capital where contemporaries of the time estimate an additional 200,000 - 600,000 victims . Adding

\footnotetext{
1 ASN, Segreterie dei Vicere, Scritture diverse, fascio 206, fasc. 229 (16 august 1656)

2 In ASN, Segreterie dei Vicere, Scritture diverse, fascio 212, fasc. 221; 13 june 1656, it is found that already in June 1656, the plague had arrived in the territories of the Prince of Caserta, brought just by fugitives. The same can be seen from ASN, Regia Camera della Sommaria, Notamenti, vol. 112, ff. 433434 (26 april 1657)

3 In the Contado di Molise it would have been brought by a doctor from Naples (ASN, Segreterie dei Vicere, Scritture diverse, fascio 213, fasc. 86; 7 maggio 1657). In Abruzzo Citra, it would spread from Chieti, where some lawyers residing in Naples had retired. (L. Del Vecchio, La peste del 1656-1657 in Abruzzo. Quadro storico-geografico- statistico, in Bullettino della Deputazione Abruzzese di Storia Patria, Annate LXVI-LXVIII (1976-1978)), p. 87

${ }^{4}$ For further information, I. Fusco, Peste, demografia e fiscalita nel Regno di Napoli del XVII secolo, FrancoAngeli, Milan 2007, cap. 3

5 ASN, Supremo Magistrato di Salute, 296, 4
}

6 The purge provided that: a fire was lit inside the houses; the walls were whitewashed; the wool was boiled or washed together with all the other washable objects, whatever was not washable, had to be disinfected with fire and left to air; coins and letters were immersed in vinegar; valueless objects were burned and in unrecoverable conditions; (Prammatica dodicesima. In S. De Renzi, Napoli nell'anno 1656, cit., pp. 203-13) 
the two data it can be said that the disease caused the death of about $43 \%^{1234567}$ of the previous population, however the mortality rates varied widely between the different centers.

In addition to the victims, we must consider the damage done to the economy of the affected territories, in fact, if on the one hand the expenses increased, on the other the revenues decreased. To the costs of the barriers to be built were added those of the guards specially recruited for the emergency, but also those relating to the payment of medical personnel. Then there were still the expenses of the lazzaretti and of the places of isolation; the costs incurred to bury the dead, build cemeteries; as well as those to support the primary needs of families unable to work; up to the purge and quarantine costs. The decrease in revenue was determined both by the demographic decrease and by the worsening of the economic situation of the various areas. With the destruction of entire families, the tax burden of those surviving, who were frequently subjected to indirect local taxes, also worsened. The economic situation of the small towns plummeted when the population was forced to neglect their economic activity, because due to the travel prohibitions it was difficult to continue agricultural, breeding, fishing, as well as trade activities, with the closure of numerous shops .

The repercussion on public finances was not long in coming, the debt of the centers increased more and more, impoverishing the provinces of the Kingdom. Nonetheless, the court continued to demand some sums, sometimes granting concessions to lands in difficulty, until the issue of the pragmatics, by the Neapolitan authorities. However, the critical issues did not end, indeed the tax debate continued for several years to come 8 .

\footnotetext{
1 Prammatica decimaterza. In S. De Renzi, Napoli nell'anno 1656, cit., pp. 213-8

2 For further information, I. Fusco Peste, Demografia e fiscalita nelRegno di Napoli delXVIIsecolo, cit., chap. 4

3 It is useful to specify that the highest estimates are provided by contemporaries. For further details I. Fusco, Peste, demografia e fiscalita nel Regno di Napoli delXVII secolo, cit., pp. 111-112

4 For further information I. Fusco, Peste, demografia e fiscalita nel Regno di Napoli delXVII secolo, cit., pp. 99-107
}

5 I. Fusco, La peste del 1656-58 nel Regno di Napoli: diffusione e mortalita, cit., pp. 115-138

${ }^{6}$ As explained by E. Nappi, in Aspetti della societa e dell'economia napoletana durante la peste, dai documenti dell'Archivio storico del banco di Napoli, edited by Banco di Napoli, Naples, 1980, cap. 2. In the Historical Archive of the Banco di Napoli (ASBN), Banco del Salvatore, there are documents certifying the expenses for the Deputation of health incurred between May $1656-1659$, for an amount equal to 190,000 ducats, to which must be added the payments made for cash of which no trace has been received

7 Ibidem, pp.133-137

8 For further information I. Fusco, Peste, demografia e fiscalita nel Regno di Napoli delXVII secolo, cit., cap. 6-7 


\section{The role of the Institutions: the Banchi Pubblici and the Pio Monte della Misericordia}

Institutions played a fundamental role in the time of the plague. Here we will examine the role of Banchi pubblici and that of Pio Monte della Misericordia, in making contributions and economic aid to support the population. Some sources also attest to public aid, which however proved insufficient and of negligible importance.First of all, it is necessary to specify that the Banchi Pubblici, as well as the Pio Monte della Misericordia of Naples, continued to work during the plague period, despite the difficulties related to the people in service, not spared from the disease .

The Banchi Pubblici, among other things, made available the hospitals connected to them, for the hospitalization of the sick belonging to their institution . They incurred expenses for the transport of plague victims to lazares and for burial . They granted awards (salary advances and bonuses) to their employees for their extraordinary work, even in the place of their deceased colleagues, and for the risk they ran . The Monte della Pieta undertook to pay a weekly subsidy of 500 ducats to the hospital of San Gennaro 12345 . Institutions suffered significant losses, both due to the reduction in banking transactions and to the failure to collect income from real estate ${ }^{6}$, some of which were covered by inheritance legacies ${ }^{7}$.

Even Pio Monte della Misericordia was affected by the infection and counted the loss of numerous confreres, in fact the financial statements drawn up every six months were prepared annually, after appointing the new governors. During the same period, the institute provided relief to people in need. Precisely the Monte allocated 11493 ducats (corresponding to more than $50 \%$ of the total outputs of the period March 1656 - February 1657) for alms to the poor of the city and its villages. About 4593 ducats derived from donations made in favor of Monte, with the specific aim of allocating them to the poor sick of the infection. Among the names of those who made these donations, the Viceroy (2400 ducats) and that of Cardinal Filomarino archbishop of Naples stand out .

1 Before the plague there were 206 Banchi pubblici officers, after which there were only 70, (E. Nappi, in Aspetti della societa e dell'economia napoletana durante la peste, dai document dell'Archivio storico del Banco di Napoli, cit., p.29

2 ASBN, Banco di Sant’Eligio, apodissario, giomale copiapolizze del 1656, matr. 303; Banco dell'Annunziata, apodissario, giornali copiapolizza del 1656, matr. 316-317

3 ASBN., Banco della Pieta, apodissario, giornale copiapolizze del 1657, matr. 462

4 ABN, Banco dei Poveri, apossidario, giornale copiapolizze del 1656, matr. 328; Banco del Salvatore, apossidario, giornale copiapolizze del 1657, matr. 66; Banco dell'Annunziata, apodissario, giornale copiapolizze del 1656, matr. 317.

5 ASBN, Banco della Pieta, apodissario, giornale copiapolizze del 1656, matr. 454

6 ASBN, Banco di Sant'Eligio, apodissario, giornale copiapolizze del 1657, matr. 305

7 ASBN, Banco della Pieta, patrimoniale, libro delle conclusioni del 1658, matr. 246, p. 162

8 Archivio Storico del Pio Monte della Misericordia di Napoli, cat. H Governo del Monte, rubr. $\mathrm{d}_{1}$ -

Governatori, Declaratorie vol. $2\left(\mathrm{Hd}_{1} / 2\right)$, pp. 277-283 


\section{Spanish flu: origins of the first great pandemic}

Over the years, epidemiologists and virologists have made several hypotheses about the origins of the pandemic flu of 1918-1919. According to a first theory, the virus was generated in the overcrowded training camps of the American army, scattered throughout the United States. Another hypothesis is that of Asian origin, based on scientific conjectures and, above all, atavistic stereotypes, which identified the East with the place of origin of the main epidemics spread in history. The theory had a wide circulation thanks to German propaganda and the erroneous association of pandemic flu with bubonic plague, present in limited areas of China, from where, according to the scholar Mask Osborne Humphries, the disease would have spread to the rest of the globe carried by Chinese workers sent to France to work in the rear of the western front. In order to reach Europe, immigrants crossed Canada, where, from the Canadian archives, it emerged that 3000 Chinese workers were hospitalized for parainfluenza symptoms ${ }^{1}$. The third hypothesis dates back to 1918, when some medical circles assumed a correlation between war and the virus. In fact, the poor sanitary conditions of the trenches and military quarters had favored the onset of infectious diseases ${ }^{2}$.

The influence was indicated by different names in the various countries and at the various times of its development. Names, sometimes exotic, that evoke expressions and testimonies of cultures of wars and tense colonial relations or even the fluctuating and deceptive course of the disease: the "fashionable disease", the "stranger", the "cursed". In France it was initially referred to as "Parma fever"; "Flanders fever" in England; "Bolshevik disease" in Poland. In Spain, however, it was called "soldier of Naples"3. But the general conditions imposed by the world war would have indissolubly and forever associated the name of Spain, and not that of Naples, with the pandemic. In fact, the reason why that terrible epidemic was identified with Spain stems from the censorship made in many countries during the First World War. The governments of the belligerent nations, fearing that panic would spread among the

1 Cf. D. Patterson - G. Pyle, The Geography and Mortality of the 1918 Influenza Pandemic, in ^Bulletin of the history of Medicine», Baltimora, John Hopkins University Press, 1/1991; A. Rasmussen, Spanish flu, in J. Winter (edited by), The Cambridge History of the First World War, Vol. III: Civil Society, Cambridge, Cambridge University Press, 2014; K. Jones, The Forgotten Pandemic: A short history of the 1918-1919 Influenza outbreak and the effect on

Kalamazoo and Western State Normal School, Honors Theses, Western Michigan University, 2013; M. Humphries, Paths of infections: the First World War and the origins of the Influenza Pandemic, in «War History», 21/2013, pp. 5581.

2 Cf. H. Phillips, Influenza Pandemic, in 1914-1918-online. International Encyclopedia of the First World War, edited by D. Ute, P. Gatrell, O. Janz, H. Jones, J. Keene, A. Kramer and B. Nasson, Berlin, Freie Universitat Berlin, 2014-10-08, doi: 10.15463/ie1418.10148, p. 11; L. van Bergen, Military Medicine, in J. Winter (edited by), The Cambridge History of the first World War, Vol. III, cit. pp. 300-301.

3 At that time in Madrid the most famous show was La cancion del olvido (The song of oblivion) which contained a hit song: the Neapolitan soldier (F. Cutolo, L'influenza spagnola del 1918-1919. La dimensione globale, il quadro nazionale e un caso locale, Pistoia, I.S.R.Pt, 2020) 
population, tried in every way not to spread the news of the pandemic. The first information leaked from Spain - which was neutral and therefore uncontrolled in the press - and pushed the other countries to believe that it was limited to Spain alone, where, however, both the Prime Minister and King Alfonso XIII fell ill. Before and after 1918, most flu pandemics developed in Asia and spread from there to the rest of the world. But the Spanish arrived almost simultaneously in Europe, Asia and North America and that makes it difficult to accurately establish the geographical origin of the virus. Historical and epidemiologic data are inadequate to identify the geographic origin of the virus, and recent phylogenetic analysis of the 1918 viral genome does not place the virus in any geographic context ${ }^{1}$.

Regardless of its origin, however, the Spanish flu can be considered the first truly "global" disease in history, second only, perhaps, in terms of number of victims, to the terrifying epidemic of black plague of the fourteenth century, and infected between 1918 and 1919 a billion men, killing twenty-one million worldwide, according to the most cautious estimates ${ }^{2}$. At first the symptoms of the disease were the same as those of a common flu: sore throat, headache, fever. But in many cases complications such as bacterial pneumonia in acute form occurred, the patients quickly developed breathing difficulties and pains arose in most of the body. Drowsiness and numbness followed, with very high fever, weak pulse, white tongue, headache. About half of the deaths occurred in the age group between twenty and forty years old. The disease spread quickly and the prevention and treatment medical countermeasures proved to be mostly imaginative, as well as vain: gargling with quinine, nebulization chambers where up to twenty people at a time inhaled formalin or zinc sulphate. It was, in general, a bad time for science, which could not find any remedy and realized that it did not have any tool to identify and neutralize the invisible agent of the disease. The reasons for such a frightening mortality - Spinney explains - were certainly multiple. To the particular virulence of the virus were added elements such as the concomitance with the Pfeiffer bacillus, the malnutrition present for years in the populations of the warring countries, the lack of antibiotics for pulmonary

\footnotetext{
1 Cf. E. Tognotti, La "spagnola" in Italia. Storia dell'influenza che fece temere la fine del mondo (19181919), Milan, FrancoAngeli, (I ed. 2020) 2015; P. Giovannini, Le malattie del corpo e della mente, in «Annali della Fondazione Ugo La Malfa. Storia e politica», XXVIII (2013), 2014, pp. 283-300; Id., L'influenza spagnola. Controllo istituzionale e reazioni popolari (1918-1919), in A. Pastore - P. Sorcinelli (ed.), Sanita e societa, vol. II, Udine, Casamassima, 1987, pp. 373-397; Id., L'influenza "spagnola" in Italia (1918-1919), in F. Magni - A Stederini - L. Zani (ed), La grande guerra e il fronte interno. Studi in onore di George Mosse, Camerino, Universita degli Studi di Camerino, 1998, pp. 123141; J.K. Taubenberger. D.M. Morens, 1918 Influenza: the Mother of All Pandemics, in «Emerging Infectious Disease», 2006, vol.12, n. 1, pp. 15-22.

2 The most recent sources are discordant. Some claim 25, others 50 million, still speculate 100 million. Cf. W. Beveridge, L'influenza. L'ultimo grande flagello, Roma 1982; N.P.A.S. Hohnson, J. Mueller, Updating the accounts: global mortality of the 1918-1920 "Spanish" influenza pandemic in «Bulletin of History of Medicine», 2002, n. 76, pp. 105-115.
} 
complications and the precarious sanitation of the soldiers in the war ${ }^{1}$. Some authors believe that the Spanish flu was a direct consequence of the war and that the conflict represented the real incubator of the virus. Influenza, in fact, was born in military camps, where men and animals were in close proximity. Most authors claim a close connection between the flu and the conflict, though the conflict was not necessarily the primary cause. The relationship between influenza and war, instead, maybe should be sought in the rapidity of the virus' transmission and its global spread. These aspects would have been determined by the crowded conditions in the trenches and in hospitals and, of course, by the long-distance displacements of large masses of soldiers and

workers ${ }^{2}$.

As in many countries of the world, in Italy the flu epidemic experienced three waves: the first coinciding with the spring of 1918, the second with autumn and the third between the winter of that year and the first months of 1919. In the Peninsula, however, the first two waves corresponded to two other crucial moments of the First World War; the offensive on the Piave in mid-June and the battle of Vittorio Veneto in late October, right at the most difficult time of the epidemic in many large cities. This circumstance certainly contributed to determine its particular diffusion and gravity with respect to other European countries that were affected by it in the same period ${ }^{3}$.

Furthermore, the pathological vulnerability of civilian populations was further increased by the geographical position of Italy, a real stretched bridge over the sea between the different fronts. The Mediterranean, a crossroads of the "pests" from the Middle Ages to the early modern age, became an epidemic sea with the Great War at the beginning of the twentieth century by virtue of the movements of men, armaments and means of the allied armies, which operated in the Near East. Of course, the transition from peace to war had not been easy in any of the belligerent countries, but in Italy it had taken on particular characteristics given the lack of connection between civil and military health, hitherto caged in a different organization and in a health bureaucracy « dependent on a dual and jealous ministerial authority, educated even in a different school, oriented towards a different ideal and destiny»4.

\footnotetext{
1 As Spinney argues, the pandemic has in fact reconfigured the human population more radically than any other event following the black plague: it influenced the course of the First World War and, probably, contributed to the outbreak of the Second; has brought India closer to independence and South Africa apartheid, has stimulated the growth of national health care and alternative medicine, the love of outdoor activities and the passion for sport and is partly responsible of the obsession of 20th century artists with the infinite fragility of the human body (Cf. L. Spinney, 1918, l'influenza spagnola. La pandemia che cambid il mondo, Marsilio, Venice, 2018).

2 Cf. P.W. Ewald, Evolution of Infection Disease, Oxford, Oxford University Press, 1994.

3 E. Tognotti, La "spagnola" in Italia.
}

4 It was only the very serious dangers of cholera, typhoid and other diseases during the battles on the Isonzo front, between the end of 1915 and the spring of 1916, which prompted, a few months after 


\section{Economic impact and social consequences of the Spanish influenza pandemic}

The pandemic had major consequences and it killed a number of famous people, including the sociologist Max Weber, the artist Gustav Klimt, the poet and writer Guillaume Apollinaire or the US President Wilson, who took the influence of the third wave and weakened considerably in the decisive weeks for the conclusion of the Treaty of Versailles, so as to induce some scholars to even establish a correlation between the effects of the disease and the terrible peace that laid the foundations for the new wars. As for the economic and social consequences, similarly to other plagues of liberal Italy, the disease was considered a disease of a social nature: it was the subordinate classes that suffered from serious health shortages, living in overcrowded neighborhoods or in rural areas lacking services Toilet. The authorities and publicists tried to attribute the disease to the conduct of the victims, stigmatizing those behaviors deemed transgressive: it was a phenomenon that also occurred on the occasion of cholera epidemics during the nineteenth century.

The pandemic, therefore, can be considered as a biological and social phenomenon, inseparable from the historical, geographical and cultural context. Therefore it is interesting to trace the evolution and dynamics of the epidemic in a country like Italy, particularly from a geographical point of view, stretching from Europe to the center of the Mediterranean, and diversified from a socio-economic point of view. While looking to the past and focusing attention on Southern Italy, therefore, it is important to make an all-round reflection on a topic of great relevance and of global interest. Several studies have found a link between social distrust and the economic crisis with devastating consequences for the economy of the time. The Spanish influence and its consequences in terms of social disintegration and generalized mistrust have had permanent consequences on individual behavior in terms of lower social trust. This loss of social confidence has limited economic growth for many decades to follow. In essence, therefore, the consequences made themselves felt for many years after the pandemic ended.

Both health services and governments proved ineffective, communication errors, also due to the post-war context, did not allow the message of social distancing to be efficiently delivered, not to mention the climate of suspicion that determined the distrust of the population. Attention is therefore placed on the errors made at the time during the two years in which the Spanish woman raged throughout the world, management errors that led to a long crisis. But in addition to the ideological

entering the war, a first form of coordination between civil and military health: the health organization established at the time made use of a mixed health commission and branches concerning war zones, prisoners and those coming from the East, an ancient outbreak of plague (M. Pietravalle, Per un ministero della Sanita e dell'assistenza pubblica in Italia, in «Nuova Antalogia», march-april 1919, vol. CC, pp. 103-117; Cf. Ministero dell'Interno, Direzione Generate della Sanita Pubblica, Atti Amministrativi (1910-20), bb. 178 bis, 179, in E. Tognotti, La "Spagnola" in Italia. 
censorship of the interventionist press and of politics, which also feared the demoralization of an army committed to the epilogue of the conflict and was therefore always ready to brand any negative news as a defeatist, there was the embarrassed self-censorship of the medical class, which it came out of the golden season of the great microbiological discoveries of the late nineteenth and early century. In the following years, the shadow of the collective memory of the great war and of what followed, and the lack of interest of great writers and journalists who knew how to give the Spanish influence the sinister sound of a pestilence, ended up confining the memory of the 1918 pandemic in the private of family stories.

Today the Spanish flu is rightly considered among the most terrible pandemics in the history of humanity, causing alterations mainly of individual behavior, but at the same time it must be considered, among the great epidemics of the past, a sort of exception as its consequences on behaviors were relatively limited, probably due to the ongoing war, as well as the censorship and the particular psychological condition that ensued. It is also true, however, that as regards Italy and in particular the South, the extent of the pandemic can only be understood by restoring the complexity of the consequences, the correlations with the conflict and its tragic demographic, social and cultural consequences. From the repercussions on the functioning of the state machine, with its repercussions on production activities and essential services, to the disruption of the daily life of the internal front due to the spread of contagion; by the conflicts between military and civil authorities on emergency management, with the priority of protecting the army exercised on the assistance of civilians; by the communication strategies of the authorities and the interventionist press, which sought to reassure the population by minimizing and censuring the seriousness of the situation, the behavior and reactions of the population, which manifested a growing mistrust for the work of the authorities ${ }^{1}$.At the end of the twentieth century, Eric J. Hobsbawm wrote: "The indications that the world of the 21st century will be better are not negligible. If the world manages not to destroy itself, the favorable odds are very strong" . The world appeared transformed by the titanic technical- scientific process of the development of capitalism, which had dominated the past two or three centuries. The future cannot be a continuation of the past and the signs of an impending historical crisis were now evident. As J. Schumpeter observed regarding the cyclical fluctuations of the capitalist economy, "they are not like the tonsils, something that can be treated separately from the rest, but are, like heartbeat, the essence of the organism that manifested" 23 . On the eve of the third millennium, the forces generated by the technical-scientific economy were now large enough to destroy the environment, that is, the material basis of human life. The short century was a century of world wars, led by the great powers and their allies in scenarios of

E. Tognotti, II mostro asiatico. Storia del colera in Italia, Rome-Bari, Laterza, 2000, p. XI, 119

2 E. J. Hobsbawm, Il secolo breve. 1914-1991; ;'era dei grandi cataclismi, Milan, Rizzoli, 1994, p.674.

3 Cfr. J. Schumpeter, Business Cycles, New York-London, 1939. 
mass destruction, culminating in the possible nuclear holocaust, which was fortunately avoided. The decades of crisis have demonstrated the limits of the various golden age policies, but without producing convincing alternatives. They revealed that the institutions had lost control over the effects of collective human actions. The two main problems on the eve of the third millennium were the demographic and the ecological problems. It was clear that a rate of economic growth such as that of the second half of the short century would have produced irreversible catastrophic consequences for the natural environment of the planet, including the human race that is part of it. It was clear that it would not destroy the planet, but it certainly would alter the type of life in the biosphere. Furthermore, modern technology would have so dramatically increased the ability of our species to transform the environment that the time available to solve the problem should not have been calculated in centuries, but in decades. The other problem was that of keeping a world population stable or, more likely, a world population oscillating around a certain quota with a slight tendency towards growth or decrease. It was evident that the movements of the world population would increase the imbalances between the different regions. On the whole, as had happened in the short century, the rich and developed countries would have been the first in which the population would have stabilized. Surrounded by poor countries with numerous young people who would have demanded modest jobs in developed countries, however sufficient to enrich a person for the standard of living of Morocco, for example, rich countries with an increasingly older population and few children would have had to choose between allow for massive immigration, which would have led to major political problems within; barricade themselves against the immigrants they would need for some activities or find some other solution. The most likely would have been to allow temporary conditional immigration, which did not give foreigners the political and social rights of citizenship, but which would have led to an informal tolerance of immigrants who, for their part, would have made no claims against the host country, because they would have considered it simply as a place to earn money from time to time, basically remaining tied to their homeland. Transport and communications at the end of the twentieth century, as well as a huge gap between skillful earnings in rich countries in poor countries, made this kind of double existence possible more than in the past $^{1}$.Certainly, in this context, it would have been difficult to predict the Covid-19 pandemic. Between the end of 2019 and the first days of 2020, the coronavirus spread to China, in the province of Hubei. The severe containment measures introduced by the Chinese authorities (isolation of large areas of the country, restrictions on mobility, interruption of numerous production activities, an obligation to quarantine for infected people) have proven overall effective in combating the extension of the contagion, but have had a strong impact on economic activity. The epidemic spread quickly to neighboring regions of China, mainly South Korea and Japan, and to

1 E. J. Hobsbawm, Il secolo breve. 1914-1991;l'era dei grandi cataclismi, cit., pp. 650 et seq. 
western countries, first in Italy and other European countries, later in the United States. The impact of the pandemic on world growth, difficult to quantify given the uncertainty about the duration and extent of the infection, will likely be very significant. The estimates on macroeconomic projections have been repeatedly revised downwards, prefiguring a global recession, accompanied by a slowdown in the dynamics of GDP, by a fall in employment and industrial production. In the latest report on the state of the global economy, drawn up by the World Bank, it is estimated that this pandemic may trigger the worst recession that the world economy has ever experienced and is likely to favor a dramatic increase in poverty levels. Experts took into account the economic situation of 183 countries and it turned out that $90 \%$ will experience a considerable drop in GDP. The data collected speak of an average reduction of about 5.2\%: more than double compared to the financial crisis of 2008 and among the worst since the Second World War onwards. The decline in global GDP in 2020 will be exacerbated by commercial, production, financial and investment connections between countries. In 2021 the recovery will be partial. Foreign trade is most affected (-12\% in 2020), due to the limitations on the movement of people, goods and services, the new US-China trade tensions and high geoeconomic uncertainty. Furthermore, the subsequent rise will be held back by the weakness of world demand ${ }^{1}$. A particular aspect of trade makes the effect of the crisis more serious and worries observers. For at least twenty years the weight and role of global value chains in world markets has grown. According to a recent World Bank report, today most of the exchange flows between countries take place within the global value chains (or Global Value Chains, GVCs), i.e. it is generated by production processes that cross country borders and involve in the production chain of goods, especially complex ones, specialized companies located in even distant areas. The role of these global value chains in this crisis appears crucial. According to some observers, this international production organization has created a fragile economic system that is more exposed to international shocks. The risk of an interruption of the supply of the inputs necessary for production is greater in a very geographically dispersed production chain. Furthermore, the presence of these production chains can amplify the transmission of shocks according to the so-called "whip effect". In the presence of a negative shock that affects many economically connected countries almost simultaneously, the slowdown in the production of an economic system supplying essential production inputs is transmitted to the downstream connected systems, reducing their production capacity, adding a further negative squeeze to the local slowdown of production (which may be due to local factors of both supply and demand), and thus amplifying the shock. The areas in which the spread of the epidemic was greater are closely linked by the GVCs in many crucial sectors, from

1 Elaborations of the Centro Studi Confindustria on Thomson Reuters data, FMI..

2 World Bank, World Development Report 2020, in L. Tajoli, La crisi globale da Covid-19 e le ripercussioni sul commercio internazionale e sulle catene globali del valore, School of Management Politecnico di Milano. 
textiles-clothing to consumer electronics. For this shock-amplifying effect, the forecasts for the global economy and international trade are more negative than in any other crisis of the past .

However, developing countries and emerging economies will suffer most from this situation: there will be poorer people and the closure of schools and the difficulty of accessing basic health care will have repercussions, in the long run, also on capital development human. The social distancing measures that led to the closure of businesses and services will impact demand and supply levels, trade and financial assets, which are expected to decrease by $3.6 \%$ per capita income and millions of people may have to live in conditions of extreme poverty .

The Monetary Fund estimates that the world economy will enter a more severe recession than that of 2008-2009, when the collapse of GDP was limited to $0.1 \%$. The different entity of the two crises is linked to their profoundly different nature: while the 2009 crisis was a financial crisis, transferred to the real economy, the current crisis derives from the paralysis of very large areas of the real economy, aimed at preventing risk of contagion. Indeed, the crisis triggered by the pandemic presents three new elements compared to the financial crisis of 2008-2009. The first is constituted by the fact that the most affected countries are the most industrialized in the world which, together, represent more than half of the world's GDP, almost two thirds of the planetary manufacture and about 40 percent of international trade. The second is that the world economy was hit when manufacturing activity slowed, due to the worsening of restrictions on trade and growing uncertainty on a global level. The third element of novelty is that the current shock is affecting the service sector more than the industry, especially in the catering, entertainment and hospitality services.

The crisis that is developing in recent months is therefore potentially more disabling, because it is generated by the blockade of economic activity on several fronts, primarily that of services, and because it affects a large part of the countries of the world. According to the estimates contained in the WEO of April, 9 out of 10 countries of the IMF members will witness a contraction of their GDP for the current year: it is therefore, in all respects, a global crisis ${ }^{12} 3$.

\section{The post-pandemic crisis in Italy}

In Italy, already at the end of March 2020, the ISTAT monthly report showed a clear picture: a sharp reduction in demand and consumption spread not only in Italy but all over the world. Exports and imports had fallen by $16 \%$, retail sales in Italy had fallen

1 Banca Mondiale, Rapporto sulle prospettive economiche globali, giugno 2020.

2 R. Leoncini, Verso ilpost emergenza Covid 19: Business as usual o nuove opportunity?, n.

12/2020. Banca d'Italia, Bollettino economico, n. 2/2020.

3 FMI, World Economic Outlook, april 2020. 
by $21 \%$, and industrial production had fallen by $28 \%{ }^{1}$. Many entrepreneurs, not only small, but also medium and large ones, have faced enormous difficulties, especially in the service sector, in particular in small shops and in the bar- restaurant-hotel chain, following the serious crisis in tourism and transport. Temporary forms of support and emergency liquidity provision were certainly essential to contain the closure of companies and the loss of jobs, but they were not sufficient. Micro entrepreneurs are undoubtedly important, they are the social fabric of many areas of Italy, especially in the South, and are the kindergarten from which larger companies are born, but the export of Made in Italy is not based on micro entrepreneurs, but on 44,050 industrial enterprises active for export with 10 or more employees. In 2017, in fact, the Italian industry exported 350 billion euros with 89.611 exporting companies and, among these, the 45.561 with less than 10 employees exported only 8 billion. The restart strategy, therefore, should focus on the 44 thousand large-scale exporting industrial enterprises, which have already driven our economy out of the 2008-2009 crisis. The Italian industrial export is the second largest in Europe after the German one and allows us to be among the top five countries in the world for the best manufacturing trade balance, with a surplus with foreign countries stably over 100 billion dollars. Thanks to the Industry 4.0 plan, our production system has grown more than that of Germany in recent years and has enormously increased its productivity, also diversifying into new sectors such as the pharmaceutical sector, where last year Italy registered the most strong growth both percentage $(+26.3 \%)$ and absolute $(+5.1$ billion dollars) among the top 15 world exporters. Growth will be stronger the more the industry is put in a position to compete better. An infrastructure plan is needed to make the country and its economy run more, which together with manufacturing is also based on agriculture, tourism and the advanced tertiary sector, often interconnected. In the 1950s, the Autostrada del Sole Highway ran cars along the peninsula and was a symbol of the economic boom. Today, modern infrastructures are needed to make data, ideas, passengers and goods run. Fiber optic, high speed and high capacity, energy saving and green energy, fight against hydrogeological instability, anti-seismic and school building, research, innovation, technological platforms, technical schools and more mathematics, engineering and medicine in the education of young people: these must be the drivers of the restart, not the welfare. Along with a reform that can no longer be postponed and a complete digitalization, from North to South of the country 2 .

The fall in consumption could cause a chain of business failures more in southern Italy than in the north of the country. The companies located in the South, in fact, with some exceptions, are mainly small companies, frequently family-run, heavily dependent on bank credit and above all oriented to selling on the internal market.

1 ISTAT, Nota mensile, april 2020.

${ }_{2}^{2}$ M.Fortis, Una nuova autostrada del Sole per ridare slancio all'economia, in "Il Sole 24 ore", 2 June 2020. 
Failures could increase the already high unemployment rate and accentuate migratory flows, especially of young people and above all of young people with high educational qualifications. It would therefore be necessary to find more resources to stimulate the southern economy by reducing the wide margins of uncertainty deriving from the ongoing epidemic. In particular, the migration of young people must be curbed and therefore the aging of the local population, which would lead to an increase in the propensity to save in the South more than it increases in the North, should be countered. This would lead to a more intense fall in consumption in the South and, given the productive structure of the companies located here and given the growing uncertainty, a fall in production and employment ${ }^{1}$. Could the solution be that, apparently utopian but susceptible to practical applications, of the so-called "partnership economy" formulated by James Meade?

\section{References}

[1] Archivio Storico del Pio Monte della Misericordia di Napoli, cat. H Governo del Monte, rubr. d1 - Governatori, Declaratorie vol. 2 (Hd1/2), pp. 277-283

[2] ASBN, Banco della Pieta, apodissario, giornale copiapolizze del 1656, matr. 454

[3] ASBN., Banco della Pieta, apodissario, giornale copiapolizze del 1657, matr. 462

[4] ASN, Segreterie dei Vicere, Scritture diverse, fascio 206, fasc. 229 (16 august 1656)

[5] ASN, Segreterie dei Vicere, Scritture diverse, fascio 208, fasc. 136 e fascio 205, fasc. not numberd; 17 may 1656

[6] Banca Mondiale, Rapporto sulle prospettive economiche globali, giugno 2020.

[7] Cf. P.W. Ewald, Evolution of Infection Disease, Oxford, Oxford University Press, 1994.

[8] Cf. S. De Renzi, Napoli nell'anno 1656, cit. p. 37 note 1; SNSP, ms. XXVI.D.5, G. Campanile, Cose degne di memoria della citta di Napoli, f. 681; Furthermore, ASN, Segreterie dei Vicere, Scritture diverse, cit., fascio 217, fasc. 126 (17 november1657)

[9] Cfr. J. Schumpeter, Business Cycles, New York-London, 1939.

[10] De Renzi, Napoli nell'anno 1656, cit., pp. 35-36

[11] E. J. Hobsbawm, Il secolo breve. 1914-1991 ;l'era dei grandi cataclismi, cit., pp. 650 et seq.

[12] E. J. Hobsbawm, Il secolo breve. 1914-1991;l'era dei grandi cataclismi, Milan, Rizzoli, 1994, p.674.

[13] E. Tognotti, II mostro asiatico. Storia del colera in Italia, Rome-Bari, Laterza, 2000, p. XI, 119

1 G.F. Davanzati, La delicata questione del Covid nelMezzogiorno, in "Il Sole 24 ore", 19 march 2020. 
[14] E. Tognotti, La "spagnola" in Italia.

[15] F. Manconi, Castigo de Dios. La grande peste barocca nella Sardegna di Filippo IV, Donzelli, Rome, 1994

[16] FMI, World Economic Outlook, april 2020.

[17] Fusco, Il ruolo dei fattori antropici e fisici nella diffusione dell'epidemia di peste del 1656-58 nel Regno di Napoli, Istituto di Studi sulle Societa del Mediterraneo, «Popolazione e Storia», 2/2015, Naples, pp. 95-113

[18] Fusco, La peste del 1656-58 nel Regno di Napoli: diffusione e mortalita, cit., pp. $115-138$

[19] G.F. Davanzati, La delicata questione del Covid nelMezzogiorno, in "Il Sole 24 ore", 19 march 2020.

[20] M.Fortis, Una nuova autostrada del Sole per ridare slancio all'economia, in "Il Sole 24 ore", 2 June 2020.

[21] Pascale Bindio, Napoli nell'anno 1656: ovvero, Documen dellapeslenza che desold Napoli nell'anno 1656, 1867

[22] Prammatica decimaterza. In S. De Renzi, Napoli nell'anno 1656, cit., pp. 2138

[23] R. Leoncini, Verso ilpost emergenza Covid 19: Business as usual o nuove opportunity?, n. 12/2020. Banca d'ltalia, Bollettino economico, n. 2/2020.

[24] SNSP, ms. XXIII.D.14, A. Rubino, Notitia di quanto e occorso in Napoli dall'anno 1648 per tutto l'anno 1657, tomo I, ff. 218-219 